\title{
EFFECTIVENESS OF TWO UNIVERSAL ADHESIVES USING TWO DIFFERENT BONDING APPROACHES
}

\author{
Manar M. Abu-Nawareg* and Rasha Ramadan Basheer**
}

\begin{abstract}
Objectives: The aim of the current study was to evaluate the resin-dentin micro-tensile bond strength ( $\mu$-TBS) using 2 types of universal adhesives with etch-and-rinse and self-etch approaches after 24 hours and 6 months of water storage.

Materials and Methods: A total of 20 extracted non-carious human molars were used in this study. Teeth were equally and randomly divided into 2 groups $(\mathrm{N}=10$ teeth) according to the type of adhesive used; Group I; Adhese ${ }^{\circledR}$ Universal and Group II; Single Bond Universal. Each group was further subdivided into 2 equal subgroups ( $n=5$ teeth) according to the bonding approach used; Subgroup A; using the self-etch (SE) approach and Subgroup B; using the etch-and-rinse (ER) approach. After bonding, each tooth was built up by resin composite, cut into sticks $(0.9 \mathrm{~mm}$ x 0.9 $\mathrm{mm}$ ) and stored in distilled water at $37^{\circ} \mathrm{C}$ for 24 hours and 6 months. Then, each stick was stressed under tension until failure using a simplified universal testing machine at a crosshead speed of 1 $\mathrm{mm} / \mathrm{min}$. Data were statistically analyzed using One-Way ANOVA, Two-Way ANOVA and Tukey HSD Tests. After $\mu$-TBS testing, all debonded surfaces were observed using a stereomicroscope at 50X magnification to determine the modes of failure, which were categorized as adhesive, cohesive or mixed failure.
\end{abstract}

Results: After 24 hours of water storage, there was no significant difference between the $\mu$-TBS exhibited by Adhese Universal using both SE and ER approaches while both approaches differed significantly when using Single Bond Universal $(\mathrm{P}=0.0003)$. Furthermore, there was no significant difference when comparing the $\mu$-TBS means of SE groups or ER groups of both adhesive systems. After 6 months of water storage at $37^{\circ} \mathrm{C}$, there was a significant decrease in the $\mu$-TBS values of all groups $(\mathrm{p}<0.0001)$ except when Adhese Universal was used with SE approach, there was no difference between the $24 \mathrm{~h}$ and the 6 month-groups $(\mathrm{p}=0.1449)$. The failure mode analysis was consistent with the $\mu$-TBS test results as the number of adhesive failures increased with decreased bond strength values.

Conclusions: When bonding resin-based composite restoratives to dentin, a separate acidetching step is not required when using Adhese Universal, but it is preferred with Single Bond Universal adhesive. Aging markedly contributes to bond degradation of universal adhesives.

KEYWORDS: Universal adhesive, etch-and-rinse, self-etch, microtensile bond strength, fracture mode analysis, water storage.

* Assistant Professor, Biomaterials Department, Faculty of Oral and Dental Medicine, Cairo University, Cairo, Egypt. ** Lecturer, Operative Department, Faculty of Dentistry, October University for Modern Sciences and Arts, Cairo, Egypt. 


\section{INTRODUCTION}

Nowadays, tooth-colored restoratives have efficiently succeeded to replace the classic predominating metallic ones in posterior teeth restoration. ${ }^{1-3}$ This is considered valuable for direct and indirect restorative techniques for bonded restorations, as direct resin-based composite (RBC) restoratives have also been accepted as efficient core 'build-up' materials that contribute significantly to the fracture resistance and retention of the extra-coronal restorations. ${ }^{4,5}$ This is mainly due to its aesthetics as well as it is associated with more conservative restorative techniques. ${ }^{6}$ To date, replacement of failed restorations is considered the most frequent procedure in daily practice, ${ }^{7}$ because of the limited longevity of available restoratives. ${ }^{2}$ Unfortunately, such procedure is accompanied by further destruction of tooth structure as a result of the removal of old restoration. ${ }^{8,9}$

Great attention has been given to adhesive dentistry in the last decades as it represents the key to success of such tooth-colored restorations. ${ }^{10}$ The attempts of improvements were all directed to the simplification of the clinical adhesive steps to decrease the needed application time, reduce the possibility of technical errors and enhance the bonding with the tooth structure. ${ }^{11}$

The inorganic composition and prismatic structure of enamel make bonding to this tooth tissue more predictable and less challenging when compared to that of dentin..$^{12,13}$ The high water and organic content, the tubular structure containing the odontoblastic processes and the variation in number and diameter of the dentinal tubules according to the proximity to the pulp contribute greatly in the magnification of the dentin bonding challenge..$^{14,15}$

Based on their action on the smear layer, adhesive systems are classified into two main classes; smear layer removal etch-and-rinse (ER) or smear layer dissolving self-etch (SE) adhesive approach. ${ }^{16}$ The two approaches are different as the former removes all the smear layer while the latter dissolves and incorporates its remnants within the hybrid layer. ${ }^{17}$ In spite of the success of the former for enamel bonding, ${ }^{18}$ durability of such approach when used for dentin bonding is questionable, because of its technique sensitivity, ${ }^{19}$ and the discrepancy in the encapsulation of the collagen fibrils because of the high water content remaining through the demineralization zone whole depth. ${ }^{20}$ Alternatively, the use of SE approach with dentin comprises the simultaneous demineralization and resin penetration resulting in the creation of a thin and a properly infiltrated hybrid layer. ${ }^{21-23}$ This had led to the preference of the selective enamel etching technique combined with a mild $\mathrm{pH}$ SE adhesive among clinicians in attempt to achieve efficient and long-lasting bonding to both tooth substances. ${ }^{24}$

In order to satisfy this need, manufacturers developed the "universal" or "multi-mode" simplified SE adhesives, ${ }^{21}$ comprising all bonding elements in a single bottle (one-step). ${ }^{25}$ It was claimed that these simplified adhesives could be applied concurrently with both ER and SE techniques, without jeopardizing the bonding efficiency. ${ }^{26,27}$ However, according to the literature, ${ }^{28-32}$ the use of such simplified SE adhesives usually result in lower in-vitro bond strength and are accompanied with inferior in-vivo durability of bonded restorations.

The achievement of strong and long-lasting bond between the tooth structure and the subsequent restoratives has always been an ambition for the dental profession. ${ }^{33,34}$ More than a few laboratory tests were recommended to test the adhesives' bonding performance; i.e. micro-tensile $(\mu \text {-TBS })^{35}$ and micro-shear $(\mu-\mathrm{SBS})^{36}$ bond strength tests. The former was the adopted one for the current study as compared to others it improves stress distribution during testing, reduces the tendency of cohesive failure in the dentin, and enables the measurements of regional differences in resin-dentin bond strength and the bond strengths of newly introduced materials. ${ }^{35,37}$ 
Furthermore, aging presents an imperative feature that may affect the longevity of resin-bonded restorations. ${ }^{37}$ To date, there is little available information concerning the performance of these newly introduced adhesives in clinical practice. ${ }^{38}$ Therefore, the aim of the current study was to evaluate the immediate and six-month resin-dentin $\mu$-TBS of two universal adhesives using the ER and SE approaches and determine the predominating failure mode in each of the tested samples. The following null hypotheses were tested: 1) The type of universal adhesive used would affect the bond strength. 2) ER adhesive approach would exhibit higher bond strength when compared to SE one. 3) Aging would significantly affect the bond strength of the universal adhesives to dentin.

\section{MATERIALS AND METHODS}

A total of 20 extracted non-carious human molars were used in this study. They were stored in $0.5 \%$ chloramine $\mathrm{T}$ solution at $4^{\circ} \mathrm{C}$ not more than one month. Low-speed diamond saw (Micromet AG, Munich, Germany) was used perpendicular to the long axis of each tooth to remove occlusal enamel and superficial dentin under water irrigation. A standardized smear layer was created on the exposed flat middle/deep coronal dentin with 320 grit wet silicon carbide paper.

\section{Samples grouping:}

The teeth were equally and randomly divided into 2 groups ( $\mathrm{N}=10$ teeth) according to the type of adhesive used; Group I; Adhese ${ }^{\circledR}$ Universal (Ivoclar Vivadent AG, Schaan, Liechtenstein) and Group II; Single Bond Universal (3M ESPE, St. Paul, MN, USA). Each group was further subdivided according to the bonding approach used into 2 equal subgroups ( $\mathrm{N}=5$ teeth); Subgroup A; using the SE mode and Subgroup B; using the ER mode.

\section{Application of adhesives and resin composite:}

The selected adhesive materials were applied to dentin according to manufacturers' instructions (Table 1). Then, five 1-mm thick layers of resin composite; Tetric EvoCeram (Ivoclar Vivadent AG, Schaan, Liechtenstein) was used with Adhese ${ }^{\circledR}$ Universal groups while Filtek Z350 XT (3M ESPE, St. Paul, MN, USA) was used with Single Bond Universal groups, were incrementally placed over the bonded dentin surface and individually polymerized for $20 \mathrm{~s}$ (Blue phase LED curing light, Ivoclar Vivadent). The type of resin composite does not play a role in the test, the composites used were selected to be compatible with their corresponding adhesive; having the same manufacturer.

\section{Micro-tensile bond strength test:}

After soaking in water at $37^{\circ} \mathrm{C}$ for 24 hours, each bonded tooth was cut into sticks $(0.9 \mathrm{~mm}$ x $0.9 \mathrm{~mm})$ using the non-trimming technique. ${ }^{39}$ Sticks obtained from each tooth were stored in separate containers in distilled water at $37^{\circ} \mathrm{C}$. Three sticks from each tooth of each group were randomly selected after 24 hours and 6 months of water storage ( 3 sticks $x$ 5 teeth/group $=15$ sticks at each time period). The experimental design of the study is presented in table 2 .

The dimensions of each stick were measured using a digital caliper to the nearest $0.01 \mathrm{~mm}$ and were recorded to calculate the bond strength. Each stick was stressed to failure under tension using a simplified universal testing machine at a crosshead speed of $1 \mathrm{~mm} / \mathrm{min}$ (Bisco Inc., Schaumburg, IL, USA).

\section{Mode of failure analysis after microtensile bond strength test:}

After $\mu$-TBS testing, all debonded surfaces were observed using a stereomicroscope (LG-P52; Olympus, Tokyo, Japan) at 50X magnification 
to determine the modes of failure, which were categorized as adhesive failure (at the dentin/ adhesive interface), cohesive failure (within the composite or dentin), and mixed failure (including both adhesive and cohesive failures).

\section{Statistical Analysis:}

Data for $\mu$-TBS test is presented as means and standard deviation (SD) values. Data explored for normality using D' Agostino-Pearson test. Two-Way ANOVA was performed between different adhesives with each bonding approach used within aging time and vice versa to assess the significance between the different groups. One Way ANOVA was used to compare between the interactions between variables followed by Tukey HSD Test to study the effect of different adhesives, bonding approaches and aging time on the mean $\mu$-TBS (MPa) within each group and subgroup; respectively. The significance level was set at $\mathrm{P} \leq 0.05$. Statistical analysis was performed with SPSS (v 20, IBM Corporation, Armonk, NY, USA) for Windows.

TABLE (1) Materials used in this study, their composition and their modes of application.

\begin{tabular}{|c|c|c|}
\hline Material & Composition & Mode of application \\
\hline $\begin{array}{c}\text { Adhese } \AA \text { Universal } \\
\text { Ivoclar Vivadent } \\
\text { AG, Schaan, } \\
\text { Liechtenstein. }\end{array}$ & $\begin{array}{c}\text { 10-MDP, 2-HEMA, Bis- } \\
\text { GMA, MCAP, D3MA, highly } \\
\text { dispersed silica, ethanol, water, } \\
\text { photoinitiators }\end{array}$ & $\begin{array}{l}\text { Etch-and-rinse approach: } \\
\text { 1. Apply N-Etch to dentin. Wait } 15 \text { seconds. Rinse thoroughly for } \\
10 \text { seconds. Blot excess water using a dry brush or mini-sponge. } \\
\text { The surface should appear glistening without pooling of water } \\
\text { (wet bonding). Do not over-dry the dentin. } \\
\text { 2. Apply a thick layer of the adhesive to dentin by scrubbing action } \\
\text { for } 10 \text { sec. Remove excess material and the solvent by a gentle } \\
\text { stream of air so that the adhesive completely covers the dentin } \\
\text { without pooling. Light cure for } 10 \text { sec. } \\
\text { Self-etch approach: } \\
\text { Apply a thick layer of the adhesive to dentin by scrubbing action for } \\
\text { 10 sec. Remove excess material and the solvent by a gentle stream } \\
\text { of air so that the adhesive completely covers the dentin without } \\
\text { pooling. Light cure for } 10 \text { sec. }\end{array}$ \\
\hline $\begin{array}{l}\text { Single Bond } \\
\text { Universal } \\
\text { 3M ESPE, St. Paul, } \\
\text { MN, USA. }\end{array}$ & $\begin{array}{l}\text { 10-MDP, 2-HEMA, silane, } \\
\text { dimethacrylate resins, } \\
\text { Vitrebond }{ }^{\mathrm{TM}} \text { methacrylate- } \\
\text { modified polyalkenoic } \\
\text { acid copolymer structure, filler, } \\
\text { ethanol, water, photoinitiators }\end{array}$ & $\begin{array}{l}\text { Etch-and-rinse approach: } \\
\text { 1. Apply Scotchbond }{ }^{\mathrm{TM}} \text { Etchant to dentin. Wait } 15 \text { seconds. Rinse } \\
\text { thoroughly for } 10 \mathrm{~seconds} \text {. Blot excess water using a dry brush } \\
\text { or mini-sponge. The surface should appear glistening without } \\
\text { pooling of water. } \\
\text { 2. Apply adhesive to dentin by scrubbing action for } 20 \mathrm{sec} \text {. Dry the } \\
\text { adhesive for } 5 \mathrm{sec} \text { and light cure for } 10 \mathrm{sec} \text {. } \\
\text { Self-etch approach: } \\
\text { Apply adhesive to dentin by scrubbing action for } 20 \mathrm{sec} \text {. Dry the } \\
\text { adhesive for } 5 \mathrm{sec} \text { and light cure for } 10 \mathrm{sec} \text {. }\end{array}$ \\
\hline
\end{tabular}

2-HEMA, 2-hydroxyethyl methacrylate; 4-META, 4-methacryloyloxyethy trimellitate anhydride; 10-MDP, 10-methacryloyloxydecyl dihydrogen phosphate; Bis-GMA, bisphenol A glycidyl methacrylate; D3MA, decandiol dimethacrylate; MCAP, methacrylated carboxylic acid polymer. 


\section{RESULTS}

\section{Micro-tensile bond strength test:}

Two-Way ANOVA showed that both adhesives with each bonding approach used as well as aging time had a significant effect on dentin $\mu$-TBS (MPa) $(P \leq 0.001, P=0.0293)$, respectively (Table 3$)$. The interaction between those variables on dentin $\mu$-TBS (MPa) means was statistically significant $(p=0.0004)$.

Means and standard deviations (SD) of dentin $\mu$-TBS (MPa) for both adhesives, bonding approaches and aging time were presented in table 4 and figure 1 .
After 24 hours of water storage, there was no significant difference between the $\mu$-TBS exhibited by Adhese Universal using both SE and ER approaches while both approaches differed significantly when using Single Bond Universal $(\mathrm{P}=0.0003)$. Furthermore, there was no significance difference when comparing the $\mu$-TBS means of SE groups or ER groups of both adhesive systems.

After 6 months of water storage at $37^{\circ} \mathrm{C}$, there was a significant decrease in the $\mu$-TBS values of all groups $(\mathrm{p}<0.0001)$ except when Adhese Universal was used with SE approach, there was no difference between the $24 \mathrm{~h}$ and the 6 months groups $(\mathrm{p}=0.1449)$.

TABLE (2): Experimental Design of the study

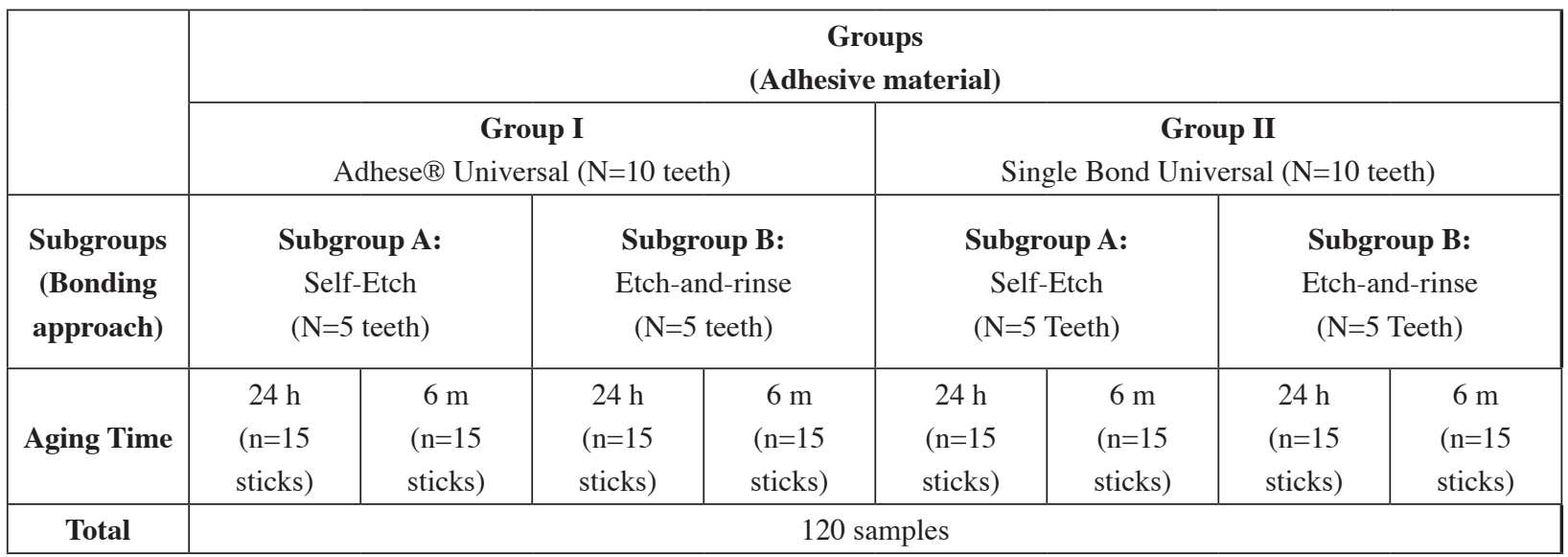

TABLE (3): Two-Way ANOVA used to study the effect of different adhesives with different bonding approaches and aging time on dentin $\mu$-TBS (MPa) means

\begin{tabular}{|l|c|c|c|c|c|}
\hline \multicolumn{1}{|c|}{ Source } & SS & df & MS & F & P-value \\
\hline Adhesives with different adhesive approaches & 624 & 1 & 624 & 61 & $<0.0001 *$ \\
\hline Aging time & 95.36 & 3 & 31.79 & 3.11 & $0.0293 *$ \\
\hline Adhesives with different adhesive approaches x Aging time & 201.4 & 3 & 67.13 & 6.56 & $0.0004 *$ \\
\hline Error & 1145.71 & 112 & 10.23 & & \\
\cline { 1 - 4 } & 2066.47 & 119 & &
\end{tabular}

(SS= Sum of Squares, $d f=$ degrees of freedom, MS= Mean Square, F=variance of the group means, Sig. = Significant (Probability level), *= Significant at $P \leq 0.05$ ) 
TABLE (4) Means and standard deviations (SD) of dentin $\mu$-TBS (MPa) for both adhesives, bonding approaches and aging time.

\begin{tabular}{|l|c|c|c|c|c|}
\hline \multicolumn{1}{|c|}{ Adhesive } & \multicolumn{2}{c|}{ Adhese ${ }^{\circledR}$ Universal } & \multicolumn{2}{c|}{ Single Bond Universal } & \multirow{2}{*}{ P-value } \\
\hline Bonding approach & SE & ER & SE & ER & \\
\hline After 24 hours & $32.2 \pm 3.26^{\mathrm{Ac}}$ & $34.5 \pm 3.19^{\mathrm{Abc}}$ & $30.8 \pm 2.75^{\mathrm{Acd}}$ & $35.7 \pm 3.28^{\mathrm{Aab}}$ & $0.0003^{*}$ \\
\hline After 6 months & $30.5 \pm 2.94^{\mathrm{Aa}}$ & $28.9 \pm 3.04^{\mathrm{Bab}}$ & $28.2 \pm 1.97^{\mathrm{Bab}}$ & $27.4 \pm 2.75^{\mathrm{Bb}}$ & $0.02^{*}$ \\
\hline P-value & 0.1449 & $<0.0001^{*}$ & $0.0059^{*}$ & $<0.0001^{*}$ & \\
\hline
\end{tabular}

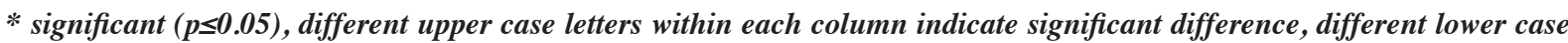
letters within each row indicate significant difference $(p \leq 0.05)$

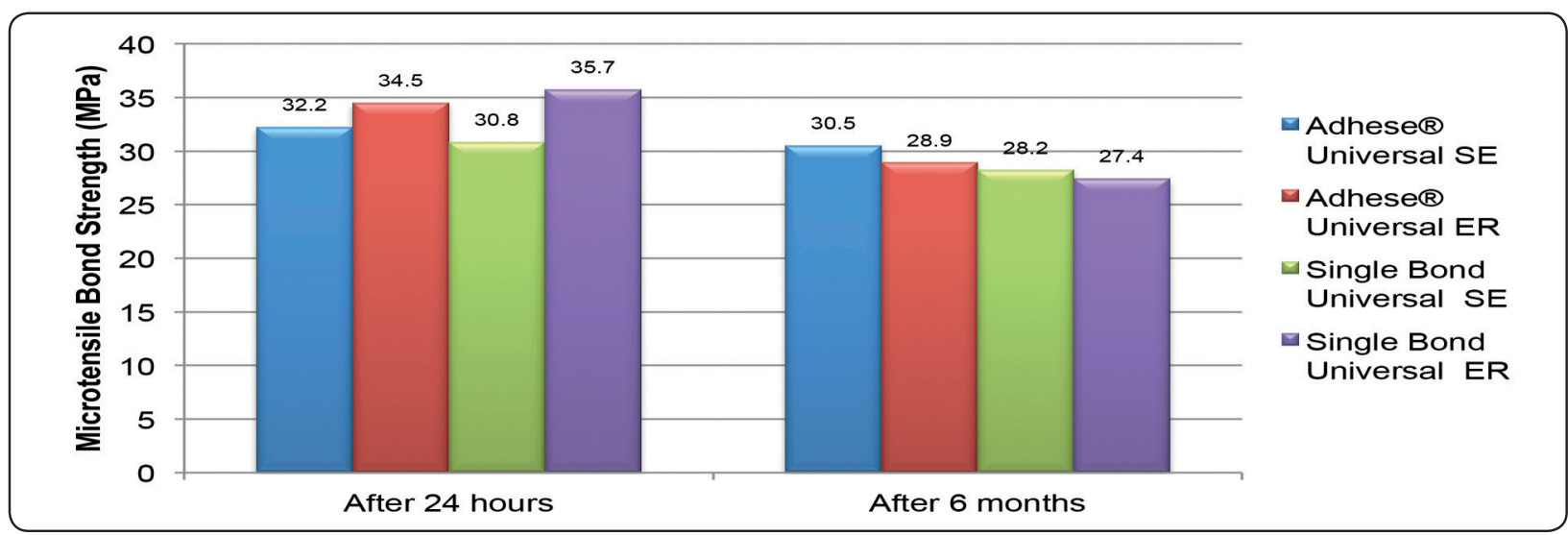

Fig (1): Column chart showing the mean dentin $\mu$-TBS (MPa) for different adhesives and bonding approaches within each aging time

\section{Effect of adhesive type (Regardless of bonding ap- proach or aging time)}

Table 5 and figure 2 show that, regardless of the bonding approach used before the application of different adhesives on dentin and regardless of the aging time, there was no statistically significant difference between the dentin $\mu$-TBS means exhibited by Adhese ${ }^{\circledR}$ Universal $(31.53 \pm 3.9 \mathrm{MPa})$ and Single Bond Universal $(30.52 \pm 4.39 \mathrm{MPa})(p=$ 0.1853).

\section{Effect of bonding approach (Regardless of adhe- sive type or aging time)}

Regardless of the adhesive type and the aging time, table 5 and figure 2 show that there was no statistically significant difference in the dentin $\mu$-TBS means between ER bonding approach
$(31.62 \pm 4.83 \mathrm{MPa})$ and $\mathrm{SE}$ bonding approach $(30.43 \pm 3.31 \mathrm{MPa})(p=0.1181)$.

Effect of aging time (Regardless of adhesive type or bonding approach)

As we can see from table 5 and figure 2, the dentin $\mu$-TBS mean decreased significantly from $(33.31 \pm 3.83 \mathrm{MPa})$ in the 24 hour-group to $(28.75 \pm 3.13 \mathrm{MPa})$ in the 6 month- group $(p<0.0001)$, regardless of the adhesive type or the bonding approach.

\section{Mode of failure:}

The fracture modes of all groups are shown in table 6 . The analysis of the failure modes indicated that the fracture pattern distribution was variable in each group. Generally, the predominant fracture 
TABLE (5) Means and standard deviations of dentin $\mu$-TBS (MPa) of each variable regardless of the other two factors

\begin{tabular}{|c|c|c|c|}
\hline \multicolumn{2}{|c|}{} & Mean and standard deviation (SD) of dentin $\mu$-TBS (MPa) & P-value \\
\hline \multirow{2}{*}{ Adhesives } & Adhese $®$ Universal & $31.53 \pm 3.9$ & \multirow{2}{*}{0.1853} \\
\cline { 2 - 4 } & Single Bond Universal & $30.52 \pm 4.39$ & \multirow{2}{*}{0.1181} \\
\hline \multirow{2}{*}{$\begin{array}{c}\text { Adhesive } \\
\text { approaches }\end{array}$} & SE & $30.43 \pm 3.31$ & \multirow{2}{*}{$<0.0001 *$} \\
\cline { 2 - 3 } & ER & $31.62 \pm 4.83$ & $33.31 \pm 3.83$ \\
\multirow{2}{*}{ Aging time }
\end{tabular}

*; significant $(p<0.05)$

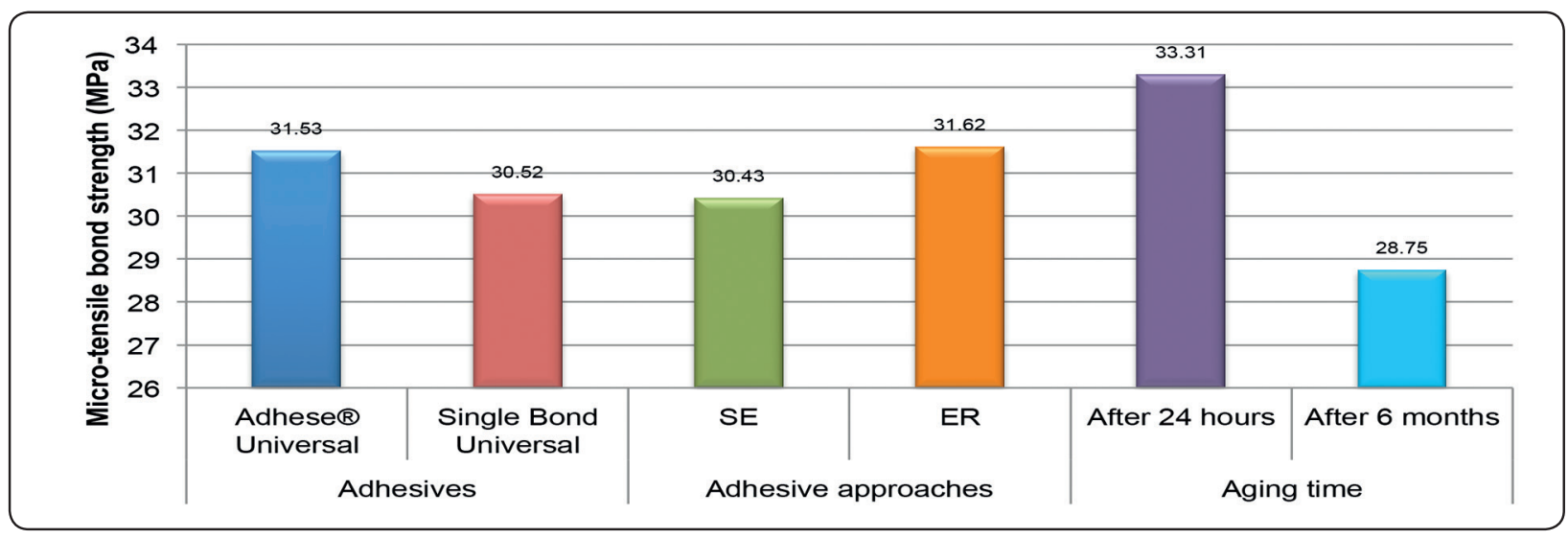

Fig (2): Column chart showing the mean dentin $\mu$-TBS (MPa) of each variable regardless of the other two factors

mode was the mixed type, irrespective of the tested group.

For Adhese ${ }^{\circledR}$ Universal with both bonding approaches, after $24 \mathrm{~h}$-water storage; most of the failures were mixed $(73.33 \%)$ while the remaining sticks $(26.67 \%)$ showed adhesive failures. After 6 months of water storage, mixed failures were still predominating $(60 \%)$ while the adhesive failures were $33.33 \%$, and there was $6.67 \%$ cohesive failure in composite.

When the Single Bond Universal adhesive was used with SE bonding approach, the $24 \mathrm{~h}$-water storage group showed $60 \%$ mixed failures and $40 \%$ adhesive failures, while after 6 months, the mixed failure dropped to $53.33 \%$ while the adhesive failures increased to $46.67 \%$. On the other hand, when Single Bond Universal adhesive was used with ER bonding approach, the $24 \mathrm{~h}$-group exhibited $66.66 \%$ mixed failure, $26.67 \%$ adhesive failures and $6.67 \%$ cohesive failure in composite while after 6 months of water storage, the mixed failure was equal to the adhesive failure $(46.67 \%)$ and there was $6.66 \%$ cohesive failure in composite.

No cohesive failure in dentin was observed in any of the tested specimens. Regardless of the adhesive type, bonding approach or aging time, there were 42 adhesive failures (35\%), 4 cohesive failures in composite (3.33\%) and 74 mixed failures (61.67\%). 
TABLE (6) Failure modes $\%$ of debonded specimens after $\mu$-TBS test of the two adhesives used, bonding approaches and aging time.

\begin{tabular}{|c|c|c|c|c|c|c|c|c|}
\hline \multirow{2}{*}{$\begin{array}{c}\text { Adhesive } \\
\text { Fracture mode }\end{array}$} & \multicolumn{2}{|c|}{ Adhese ${ }^{\circledR}$ Universal (SE) } & \multicolumn{2}{|c|}{$\begin{array}{c}\text { Adhese }{ }^{\circledR} \text { Universal } \\
\text { (ER) }\end{array}$} & \multicolumn{2}{|c|}{$\begin{array}{l}\text { Single Bond Universal } \\
\text { (SE) }\end{array}$} & \multicolumn{2}{|c|}{$\begin{array}{l}\text { Single Bond Universal } \\
\text { (ER) }\end{array}$} \\
\hline & $24 \mathrm{~h}$ & $6 \mathrm{~m}$ & $24 \mathrm{~h}$ & $6 \mathrm{~m}$ & $24 \mathrm{~h}$ & $6 \mathrm{~m}$ & $24 \mathrm{~h}$ & $6 \mathrm{~m}$ \\
\hline Adhesive Failure & $\begin{array}{c}4 \\
26.67 \%\end{array}$ & $\begin{array}{c}5 \\
33.33 \%\end{array}$ & $\begin{array}{c}4 \\
26.67 \%\end{array}$ & $\begin{array}{c}5 \\
33.33 \%\end{array}$ & $\begin{array}{c}6 \\
40 \%\end{array}$ & $\begin{array}{c}7 \\
46.67 \%\end{array}$ & $\begin{array}{c}4 \\
26.67 \%\end{array}$ & $\begin{array}{c}7 \\
46.67 \%\end{array}$ \\
\hline $\begin{array}{l}\text { Cohesive in } \\
\text { Composite }\end{array}$ & $\begin{array}{c}0 \\
0 \%\end{array}$ & $\begin{array}{c}1 \\
6.67 \%\end{array}$ & $\begin{array}{c}0 \\
0 \%\end{array}$ & $\begin{array}{c}1 \\
6.67 \%\end{array}$ & $\begin{array}{c}0 \\
0 \%\end{array}$ & $\begin{array}{c}0 \\
0 \%\end{array}$ & $\begin{array}{c}1 \\
6.67 \%\end{array}$ & $\begin{array}{c}1 \\
6.67 \%\end{array}$ \\
\hline $\begin{array}{l}\text { Cohesive in } \\
\text { Dentin }\end{array}$ & $\begin{array}{c}0 \\
0 \%\end{array}$ & $\begin{array}{c}0 \\
0 \%\end{array}$ & $\begin{array}{c}0 \\
0 \%\end{array}$ & $\begin{array}{c}0 \\
0 \%\end{array}$ & $\begin{array}{c}0 \\
0 \%\end{array}$ & $\begin{array}{c}0 \\
0 \%\end{array}$ & $\begin{array}{c}0 \\
0 \%\end{array}$ & $\begin{array}{c}0 \\
0 \%\end{array}$ \\
\hline Mixed & $\begin{array}{c}11 \\
73.33 \%\end{array}$ & $\begin{array}{c}9 \\
60 \%\end{array}$ & $\begin{array}{c}11 \\
73.33 \%\end{array}$ & $\begin{array}{c}9 \\
60 \%\end{array}$ & $\begin{array}{c}9 \\
60 \%\end{array}$ & $\begin{array}{c}8 \\
53.33 \%\end{array}$ & $\begin{array}{c}10 \\
66.66 \%\end{array}$ & $\begin{array}{c}7 \\
46.67 \%\end{array}$ \\
\hline Total & $\begin{array}{c}15 \\
100 \%\end{array}$ & $\begin{array}{c}15 \\
100 \%\end{array}$ & $\begin{array}{c}15 \\
100 \%\end{array}$ & $\begin{array}{c}15 \\
100 \%\end{array}$ & $\begin{array}{c}15 \\
100 \%\end{array}$ & $\begin{array}{c}15 \\
100 \%\end{array}$ & $\begin{array}{c}15 \\
100 \%\end{array}$ & $\begin{array}{c}15 \\
100 \%\end{array}$ \\
\hline
\end{tabular}

\section{DISCUSSION}

Adhesive dentistry is a swiftly developing discipline. ${ }^{33}$ New products are introduced in the market at an exceptionally fast rate..$^{40}$ Although clinical experiments are considered the best to test the performance of dental restorations, they are unable to identify the exact cause of failure because of the concurrent effect of different factors and different stresses on restorations within the oral environment. ${ }^{33}$ On the other hand, lab testing can assess the effect of a single variable whereas all others are kept constant. ${ }^{24}$

The results of our study rejected the first null hypothesis that stated that the type of universal adhesive used would affect the dentin bond strength as, regardless of the bonding approach used and the aging time, there was no statistically significant difference in the dentin $\mu$-TBS means between Adhese ${ }^{\circledR}$ Universal $(31.53 \pm 3.9 \mathrm{MPa})$ and Single Bond Universal (30.52 $\pm 4.39 \mathrm{MPa})$ adhesives ( $p=$ 0.1853 ). This may be attributed to the compositional similarity between the two universal adhesives used in this research, as an example; both comprise in their ingredients 10-methacryloyloxydecyl dihydrogen phosphate monomer (MDP) that creates a strong nano-layer along the adhesive interface through its chemical bond to the hydroxyapatite (HA) of dentin..$^{41-43}$ Furthermore, the more complex composition of the Single Bond Universal did not seem to significantly affect the bond strength when compared to the simpler Adhese ${ }^{\circledR}$ Universal, as an example; the former contains silane and Vitrebond ${ }^{\mathrm{TM}}$ methacrylate-modified polyalkenoic acid copolymer structure (table 1), this was not in agreement with many other studies, ${ }^{28-32}$ who supported the idea that the increase in the complexity of the composition of the bonding agent would compromise its bond strength.

Also, our study showed that when Adhese Universal was used, there was no statistically significant difference in the dentin $\mu$-TBS means

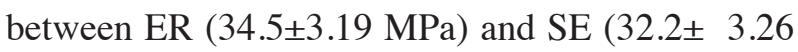
$\mathrm{MPa})$ bonding approaches $(p=0.0003)$. This was in coincidence with Zeidan et al., 2017,,$^{21}$ who proved that universal adhesives performed well in conjunction with either ER and SE approaches 
comparable to conventional adhesive systems with regards to dentin bond strengths. They concluded that this enables the clinician to flexibly choose one adhesive for all purposes. Moreover, Hanabusa et al., 2012, ${ }^{26}$ and Chen et al., 2015, ${ }^{27}$ agreed with these results as they stated that the use of the ER and the SE approaches with the universal adhesives did not alter their bonding efficiency.

This was not in agreement with Muñoz et al., $2013,{ }^{44}$ who proved that the use of the ER approach in conjunction with the universal adhesives resulted in higher bond strength when compared to the SE one, which they attributed to the presence of the smear layer in the latter that represented a true physical obstacle that hinders efficient resin penetration within the dentinal surface..$^{45}$ Moreover, many authors, ${ }^{45-47,26}$ stated that the application of one-step SE adhesive on phosphoric acid-etched dentin substrate improved its bonding performance since it causes total removal of the smear layer and demineralization of the superficial dentin, thus resulting in increase in the adhesive impregnation and hence the formation of a well infiltrated hybrid layer. In the contrary, Torii et al., 2002, ${ }^{48}$ and Van Landuyt et al., 2006, ${ }^{49}$ demonstrated that the use of SE adhesives on phosphoric acid-etched dentin surface would result in decreased bond strengths as this brings up all disadvantages of etch and rinse technique including improper penetration of the adhesive into deeply etched dentinal surface resulting in increased nanoleakage. Ozer and Blatz, $2013,{ }^{50}$ also favored the use of the SE adhesives on dentin and limit the acid etching step to enamel.

Furthermore, Erhardt, et al., 2008,,$^{51}$ stated that the effect of phosphoric acid dentin etching before the application of SE adhesives on bond strength is material dependent. This supported the results of the current study since ER bonding approach exhibited significantly $(\mathrm{p}<0.0003)$ higher bond strength $(35.7 \pm 3.28 \mathrm{MPa})$ than the SE approach $(30.8 \pm 2.75$ $\mathrm{MPa}$ ) when Single Bond Universal was used. This may be attributed to the existence of polyalkenoic acid copolymer in the composition of Single Bond Universal. Generally, presence of polyalkenoic acid copolymer in any material enhances the chemical bonding with the tooth structure. However, in case of Single Bond Universal, polyalkenoic acid copolymer might have competed with the MDP for bonding to the calcium of the HA, which might have deprived this adhesive from the continuous strong nano-layer created by the MDP at the resin-dentin interface. This might have resulted in bond strength less than the mechanical bonding provided by the ER approach. This was supported by Yoshihara et al., 2012,52 and Muñoz et al., 2013.44 as well as Yoshihara et al., 2010,53 and Tian et al., 2016,54 who stated that the ionic bond present in MDP-Ca salt was the most stable amongst other functional monomers and thus resulted in the creation of a stronger adhesive interface. This may also explain the higher bond strength of Adhese Universal compared to Single bond Universal when each was used with SE approach despite of the lack of significance between both $(\mathrm{p}=0.0609)$.

Moreover, the different behavior of the two tested materials may be attributed to the difference in the $\mathrm{pH}$ values of the two tested universal adhesives; Adhese Universal (2.5, mild SE adhesive) and Single Bond Universal (2.7, ultramild SE adhesive), which might have affected their interaction with the dentin substrate. This was in agreement with Rosa, et al., 2015,,$^{55}$ who stated that the ultra-mild multi-mode adhesives showed an improvement in the dentin bond strength when preceded by phosphoric acid etching as they are not able to properly "etch" and "prime" the dentin substrate, while prior acid etching did not seem to affect the dentin bond strength for mild SE universal adhesives. Accordingly, the second null hypothesis, that stated that ER bonding approach would exhibit higher bond strength when compared to SE one, was partially rejected. 
Based on the present study, the third null hypothesis that declared that aging would significantly affect the bond strength of universal adhesives was accepted. As the dentin $\mu$-TBS mean decreased significantly from $(33.31 \pm 3.83 \mathrm{MPa})$ in the 24 hour-group to $(28.75 \pm 3.13 \mathrm{MPa})$ in the 6 month-group ( $<<0.0001)$, regardless of the adhesive type or bonding approach. The results of the current study conform to earlier ones ${ }^{56-59}$ suggesting that water storage decreases resin-dentin bond strength values. This could be explained by the hydrolytic effect of water on the ester bonds of the adhesive used,$^{37}$ resulting in loss of the resin mass ${ }^{60}$ This is considered to be one of the key causes of resin degradation inside the hybrid layer resulting in decrease of dentin adhesives bond strengths with time. ${ }^{61,62}$ This also agreed with Koshiro et al., 2005, ${ }^{41}$ who proved that in absence of enamel protection, the dentin bond degraded, ${ }^{63,64}$ and the bond strength decreased due to the direct exposure of resin-dentin interfaces to water. This was not in agreement with Zeidan et al., 2017, ${ }^{21}$ who stated that storage of universal adhesives in water did not affect bond strengths for both the SE and the ER approaches.

On the other hand, regarding the influence of the two universal adhesives in correlation to the bonding approaches used, there was a significant decrease in the 6 month $\mu$-TBS values of all groups when compared to the $24 \mathrm{~h}$ values ( $\mathrm{p}<0.0001)$ except when Adhese Universal was used with SE approach, there was no difference between the $24 \mathrm{~h}$ and the 6 months groups $(\mathrm{p}=0.1449)$. This may be due to the strong nanolayer created by MDP at the resin dentin interface which resulted in more stable bond strength. This was in agreement with Yoshihara et al., 2010, ${ }^{53}$ and Tian et al., 2016, ${ }^{54}$ whose statement about the ionic bond present in MDP-Ca salt may clarify the previously proven favorable bond strength of these adhesives and clinical longevity of corresponding restorations,${ }^{24}$ as a result of hindrance of micro and nanoleakage. ${ }^{65}$ Furthermore, Muñoz et al., 2013, ${ }^{44}$ added that the deposition of such salt along the adhesive interface resulted in high bond stability, ${ }^{53,66}$ which has been previously proven both in in-vitro and in-vivo studies. . $3,67-71^{-}$

Furthermore, Single bond Universal used with SE approach exhibited decreased $6 \mathrm{~m}$ bond strength values compared to the $24 \mathrm{~h}$ values. This may be explained by the more complex nature of the Single Bond Adhesive, which according to the literature, ${ }^{28-32}$ results in lower durability of the bonded interfaces. Also, as mentioned before, the presence of the polyalkenoic acid that might have competed with MDP for the Ca of the Hydroxyapatite, depriving the resin-dentin interface created by this adhesive from the strong nanolayer that is responsible for the stability of such interface. This was supported by several studies. ${ }^{44,52-54}$ However, Sofan et al., 2017, ${ }^{72}$ did not agree as they stated that the existence of polyalkenoic acid copolymer, present in the composition of the latter, may improve the bond durability through preventing the water sorption and the hydrolytic breakdown of the adhesive interface over time that represent the main reasons of bond failure. ${ }^{63,73}$

The drop in the bond strengths exhibited by both adhesives when ER approach was used may be attributed to the high water content remaining at the deep demineralization zone in the ER approach leading to inconsistency in resin encapsulation of the collagen fibrils and hence make the durability of such approach when used for dentin bonding questionable. This was supported by Wang and Spencer, 2003, ${ }^{20}$ and Van Meerbeek et al., 2005, ${ }^{19}$ who related the reason of such deterioration to technique sensitivity. This was also in agreement with Santos et al, 2014, ${ }^{12}$ who claimed that dentin etching limits the capability for monomer infiltration to its full extent as it excessively exposes the collagen fiber network, ${ }^{45,74,75}$ making it vulnerable to degradation and ends in bond failure and reduction of clinical longevity. ${ }^{76,77}$ Muñoz et al, 2013, ${ }^{44}$ also agreed as they reported that the ER approach results in increased demineralization and creation of a HA depleted, collagen-rich, network, ${ }^{24,78,79}$ thus raising the jeopardy of nanoleakage. ${ }^{20,80-82}$ Mena-Serrano 
et al., $2013,^{83}$ did not agree with the results of the current study as they found that the behavior of the universal adhesives is not affected by the bonding approach at 6 months. Also Perdigão et al., 2014, ${ }^{84}$ blamed the highly hydrophilic nature of one-step SE adhesives in the increase of the liability of degradation by time, because of their attraction to water, ${ }^{85,86}$ which is directly proportional to their hydrophilic properties. ${ }^{87}$

The analysis of mode of failure is an essential factor to exemplify tests results. ${ }^{88}$ In the current study, the analysis of the failure mode was consistent with the $\mu$-TBS test results as the groups that showed the least bond strength; Single Bond Universal with SE and ER approaches after 6 month storage in water $(28.2 \pm 1.97$ and $27.4 \pm 2.75$ $\mathrm{MPa}$, respectively), showed the highest adhesive failure among all tested groups (46.67\%). Also, regarding the effect of aging within each group, we can correlate the drop in the bond strength after 6 month storage in water with the increasing number of adhesive failure of such specimens. This was in agreement with Armstrong, et al., 2001, ${ }^{89}$ who demonstrated the indirect relationship between the bond strength and the adhesive failure. This also coincided with Proença et al., 2007,46 who stated that the relative lower percentage of adhesive failures after the $\mu$-TBS testing might be related to superior hybridization.

\section{CONCLUSIONS}

Within the limitations of this study, the following could be concluded: When bonding resin-based composite restoratives to dentin, a separate acidetching step is not required when using Adhese Universal, but it is preferred with Single Bond Universal adhesive. Aging markedly contributes to bond degradation of universal adhesives. Further invitro and in-vivo research work is recommended to test the 2-5 year stability of resin-dentin interfaces using universal adhesives.

\section{REFERENCES}

1. Forss H, Widstrom E. Reasons for restorative therapy and the longevity of restorations in adults. Acta Odontol Scand, 2004; 62(2):82-86.

2. Sunnegardh-Gronberg K, van Dijken JWV, Funegard U, Lindberg A, Nilsson M. Selection of dental materials and longevity of replaced restorations in Public Dental Health clinics in northern Sweden. J Dent, 2009; 37:673-678.

3. Kopperud SE, Tveit AB, Gaarden T, Sandvik L, Espelid I. Longevity of posterior dental restorations and reasons for failure. Eur J Oral Sci, 2012; 120:539-548.

4. Wassell R W, Smart E R, St. George G. Crowns and other extra-coronal restorations: Cores for teeth with vital pulps. Br Dent J, 2002; 192:499-509.

5. Felton DA, Webb EL, Kanoy BE, Cox CF. Pulpal response to threaded pin and retentive slot techniques: a pilot investigation. J Prosthet Dent, 1991; 66:597-602.

6. Ástvaldsdóttir Á, Dagerhamn J, van Dijken JW, NaimiAkbar A, Sandborgh-Englund G, Tranæus S5, Nilsson M. Longevity of posterior resin composite restorations in adults - A systematic review. J Dent, 2015; 43(8):934-954.

7. Clarkson JE, Worthington HV, Davies RM. Restorative treatment provided over five years for adults regularly attending general dental practice. J Dent, 2000; 28:233-239.

8. Brantley CF, Bader JD, Shugars DA, Nesbit SP. Does the cycle of re-restoration lead to larger restorations? J Am Dent Assoc, 1995; 126:1407-1413.

9. Elderton RJ, Nuttall NM. Variation among dentists in planning treatment. Br Dent J, 1983; 154:201-206.

10. Gateva N, Gusiyska A, Stanimirov P, Raychev I, Kabaktchieva R. Biodegradation and Dentin Bonding Effectiveness of one "Universal" Self-etch Adhesive Used in Multi-mode Manner. J of IMAB. 2017; 23(1):1510-1515.

11. Marchesi G, Frassetto A, Mazzoni A, Apolonio F, Diolosa M, Cadenaro M, et al. Adhesive performance of a multimode adhesive system: 1-year in vitro study. J Dent, 2014; 42(5):603-612.

12. Santos R, Lima E, Pontes M, Nascimento A, Montes M, Braz R. Bond strength to dentin of total-etch and self-etch adhesive systems. Rev Gaucha Odontol, 2014; 62(4):365370 .

13. Perdigão J, Gomes G, Lopes MM. Influence of conditioning time on enamel adhesion. Quintessence Int, 2006; 37(1):35-41.

14. Macari S, Gonçalves M, Nonaka T, Santos JM. Scanning 
electron microscopy evaluation of the interface of three adhesive systems. Braz Dent J, 2002; 13(1):33-38.

15. Orellana N, Ramirez R, Roig M, Giner L, Mercade M, Duran F, et al. Comparative Study of the microtensile bond strength of three different total etch adhesives with different solvents to wet and dry dentin: in vitro test. Acta Odontol Latinoam, 2009; 22(1):47-56.

16. Sousa Y, Mergulhão V, Canto C, Torban P, Figueiroa A, Braz R. Dentin Bond Strength of Universal Adhesive Systems under Different Strategies: Self-Etch (SE) and Etchand-Rinse (ER). EC Dent Sci, 2017; 7(2):66-72.

17. Giannini M, Makishi P, Ayres A, Vermelho P, Fronza B, Nikaido T, Tagami J. Self-Etch Adhesive Systems: A Literature Review. Braz Dent J, 2015; 26(1), 3-10.

18. Beier US, Kapferer I, Burtscher D, Dumfahrt H. Clinical performance of porcelain laminate veneers for up to 20 years. Int J Prosthodont, 2012; 25:79-85.

19. Van Meerbeek B, Van Landuyt K, De Munck J, Hashimoto M, Peumans M, Lambrechts P, Yoshida Y, Inoue S, Suzuki K. Technique sensitivity of contemporary adhesives. Dent Mater J, 2005; 24:1-13.

20. Wang Y, Spencer P. Hybridization efficiency of the adhesive/dentin interface with wet bonding. J Dent Res, 2003; 82:141-145.

21. Zeidan L, Reis A, Cassoni A, Rodrigues J. Effect of six month storage on microtensile bond strength of new elective etching adhesive system on dentin in self-etching or etch-and-rinse approach. Saudi J Dent Res, 2017; 8:5-10.

22. Shinohara MS, Oliveria MT, Hipolito VD, Giannini M, Goes MF. SEM analysis of the acid-etched enamel patterns promoted by acidic monomers and phosphoric acids. J Appl Oral Sci, 2006; 14:427-435.

23. Tay FR, Sano H, Carvalho R, Pashley E, Pashey D. An ultrastructural study of the influence of acidity of self-etching primers and smear layer thickness on bonding to intact dentin. J Adhes Dent, 2000; 2:83-98.

24. Van Meerbeek B, De Munck J, Yoshida Y, Inoue S, Vargas M, Vijay P, Van Landuyt K, Lambrechts P, Vanherle G. Buonocore memorial lecture. Adhesion to enamel and dentin: current status and future challenges. Oper Dent, 2003; 28(3):215-235.

25. Isolan CP, Valente LL, Münchow EA, Basso GR, Pimentel AH, Schwantz JK, Da Silva AV, Moraes RR. Bond strength of a universal bonding agent and other contemporary dental adhesives applied on enamel, dentin, composite, and porcelain. Appl Adhes Sci, 2014; 2:1-10.
26. Hanabusa M, Mine A, Kuboki T, Momoi Y, Van Ende A, Van Meerbeek B, De Munck J. Bonding effectiveness of a new 'multi-mode' adhesive to enamel and dentine. J Dent, 2012; 40(6):475-484.

27. Chen C, Niu LN, Xie H, Zhang ZY, Zhou LQ, Jiao K, Chen J, Pashley D, Tay F. Bonding of universal adhesives to dentine - Old wine in new bottles? J Dent, 2015; 43(5): 525-36.

28. Hafer M, Schneider H, Rupf S, Busch I, Fuchss A, Merte I, Jentsch H, Haak R, Merte K. Experimental and clinical evaluation of a self-etching and an etch-and-rinse adhesive system. J Adhes Dent, 2013; 15(3):275-286.

29. Heintze SD, Ruffieux C, Rousson V. Clinical performance of cervical restorations - a meta-analysis. Dent Mater, 2010; 26(10):993-1000.

30. De Munck J, Van Landuyt K, Peumans M, Poitevin A, Lambrechts P, Braem M, Van Meerbeek B. A critical review of the durability of adhesion to tooth tissue: methods and results. J Dent Res, 2005; 84:118-132.

31. Munoz MA, Sezinando A, Luque-Martinez I, Szesz AL, Reis A, Loguercio AD, Bombarda NH, Perdigao J. Influence of a hydrophobic resin coating on the bonding efficacy of three universal adhesives. J Dent, 2014; 42:595-602.

32. Tuncer D, Yazici AR, Ozgunaltay G, Dayangac B () Clinical evaluation of different adhesives used in the restoration of non-carious cervical lesions: 24-month results. Aust Dent J, 2013; 58:94-100.

33. Hegde M, Manjunath J. Bond strength of newer dentin bonding agents in different clinical situations. Oper Dent, 2011; 36(2):169-176.

34. Stangel I, Ellis TH, Sacher E. Adhesion to tooth structure mediated by contemporary bonding systems. Dent Clin North Am. 2007; 51(3):677-694.

35. Sano H, Shono T, Sonoda H, Takatsu T, Ciucchi B. Relationship between surface area for adhesion and tensile bond strength - evaluation of a micro-tensile bond test. Dent Mater, 1994; 10:236-240.

36. Shimada Y, Senawongse P, Harnirattisai C, Burrow MF, Nakaoki Y, Tagami J. Bond strength of two adhesive systems to primary and permanent enamel. Oper Dent, 2002; 27:403-409.

37. Cetin A, Unlu N, Cebeb M. Effects of aging on the bond strength of self-etching adhesives and resin luting cements. J Dent Sci, 2013; 8:61-67.

38. Gateva N, Gusiyska A, Stanimirov P, Raychev I, Kabaktchieva R. Biodegradation and dentin bonding ef- 
fectiveness of one "universal" self-etch adhesive used in multi-mode manner. J of IMAB, 2017; 23(1):1510-1515.

39. Shono Y, Ogawa T, Terashita M, Carvalho RM, Pashley EL, Pashley DH. Regional measurement of resin-dentin bonding as an array. J Dent Res, 1999; 78: 699-705.

40. Naughton WT, Latta MA. Bond strength of composite to dentin using self etch adhesive systems. Quintessence Int, 2005; 36(4):259-262.

41. Koshiro K, Yoshida Y, De Munck J, Nagakane K, Suzuki K, Sano H, Van Meerbeek B. Hydrolytic stability of self-etch adhesives bonded to dentin. J Dent Res, 2005; 84:1160-1164.

42. Waidyasekera K, Nikaido T, Weerasinghe DS, Ichinose S, Tagami J. Reinforcement of dentin in self-etch adhesive technology: a new concept. J Dent, 2009; 37:604-609.

43. Peumans M, De Munck J, Van Landuyt KL, Poitevin A, Lambrechts P, Van Meerbeek B. Eight-year clinical evaluation of a 2-step self-etch adhesive with and without selective enamel etching. Dent Mater, 2010; 26:1176-1184.

44. Muñoz M, Luque I, Hass V, Reis A, Loguercio A, Bombarda N. Immediate bonding properties of universal adhesives to dentine. J Dent, 2013; 41(5):404-411.

45. Kenshima S, Reis A, Uceda-Gomez N, Tancredo Lde L, Filho LE, Nogueira FN, Loguercio AD. Effect of smear layer thickness and $\mathrm{pH}$ of self-etching adhesive systems on the bond strength and gap formation to dentin. J Adhes Dent, 2005; 7:117-126.

46. Proença JP, Polido M, Osorio E, Erhardt MC, Aguilera FS, García-Godoy F, Osorio R, Toledano M. Dentin regional bond strength of self-etch and total-etch adhesive systems. Dent Mater, 2007; 23(12):1542-1548.

47. Taschner M, Nato F, Mazzoni A, Frankenberger R, Falconi M, Petschelt A, Breschi L. Influence of preliminary etching on the stability of bonds created by one-step self-etch bonding systems. Eur J Oral Sci, 2012; 120:239-248.

48. Torii Y, Itou K, Nishitani Y, Ishikawa K, Suzuki K. Effect of phosphoric acid etching prior to self-etching primer application on adhesion of resin composite to enamel and dentin. American J Dent, 2002; 15(5):305-308.

49. Van Landuyt KL, Peumans M, De Munck J, Lambrechts P, Van Meerbeek B. Extension of a one-step self-etch adhesive into a multi-step adhesive. Dent Mater, 2006; 22(6):533-544.

50. Ozer F, Blatz MB. Self-etch and etch-and-rinse adhesive systems in clinical dentistry. Compend Contin Educ Dent, 2013; 34(1):12-18.
51. Erhardt MC, Osorio E, Aguilera FS, Proenca JP, Osorio R, Toledano M. Influence of dentin acid-etching and $\mathrm{NaOCl}-$ treatment on bond strengths of self-etch adhesives. American J Dent, 2008; 21(1):44-48.

52. Yoshihara K, Nagaoka N, Hayakawa S, Torii Y, Ogawa T, Osaka A, Meerbeek BV. Self-assembled nano-layering at the adhesive interface. J Dent Res, 2012; 91:376-381.

53. Yoshihara K, Yoshida Y, Nagaoka N, Fukegawa D, Hayakawa S, Mine A, Nakamura M, Minagi S, Osaka A, Suzuki K, Van Meerbeek B. Nano-controlled molecular interaction at adhesive interfaces for hard tissue reconstruction. Acta Biomater, 2010; 6(9):3573-3582.

54. Tian F, Zhou L, Zhang Z, Niu L, Zhang L, Chen C, Zhou J, Yang H, Wang X, Fu B, Huang C, Pashley DH, Tay FR. Paucity of nanolayering in resin-dentin interfaces of MDPbased adhesives. J Dent Res, 2016; 95(4):380-387.

55. Rosa WL, Piva E, Silva AF. Bond strength of universal adhesives: A systematic review and meta-analysis. J Dent. 2015; 43(7):765-76.

56. Gwinnett AJ, Yu S. Effect of long-term water storage on dentin bonding. Am J Dent, 1995; 8:109-111.

57. Burrow MF, Satoh M, Tagami J. Dentin bond durability after three years using a dentin bonding agent with and without priming. Dent Mater, 1996; 12:302-307.

58. Mitsui FH, Peris AR, Cavalcanti AN, Marchi GM, Pimenta LA. Influence of thermal and mechanical load cycling on microtensile bond strengths of total and self-etching adhesive systems. Oper Dent, 2006; 31:240-247.

59. Xie C, Han Y, Zhao XY, Wang ZY, He HM. Microtensile bond strength of one- and two-step self-etching adhesives on sclerotic dentin: the effects of thermocycling. Oper Dent, 2010, 35(5):547-555

60. Tay FR, Pashley DH. Have dentin adhesives become too hydrophilic? J Can Dent Assoc, 2003; 69:726-731.

61. Shono Y, Terashita M, Shimada J, et al. Durability of resin dentin bonds. J Adhes Dent, 1999; 3:211-218.

62. Armstrong SR, Keller JC, Boyer DB. The influence of water storage and $\mathrm{C}$-factor on the dentin-resin composite $\mu$-TBS and debond pathway utilizing a filled and unfilled adhesive resin. Dent Mater, 2001; 17:268-276.

63. De Munck J, Van Meerbeek B, Yoshida Y, Inoue S, Vargas M, Suzuki K, Lambrechts P, Vanherle G. Four-year water degradation of total-etch adhesives bonded to dentin. J Dent Res, 2003; 82:136-140.

64. Shirai K, De Munck J, Yoshida Y, Inoue S, Lambrechts P, Suzuki K, Shintani H, Van Meerbeek B. Effect of cavity configuration and aging on the bonding effectiveness of six adhesives to dentin. Dent Mater, 2005; 21:110-124. 
65. Yoshida Y, Nagakane K, Fukuda R, Nakayama Y, Okazaki M, Shintani H, Inoue S, Tagawa Y, Suzuki K, De Munck J, Van Meerbeek B. Comparative study on adhesive performance of functional monomers. J Dent Res, 2004; 83(6):454-458

66. Yoshida Y, Yoshihara K, Nagaoka N, Hayakawa S, Torii Y, Ogawa T, Osaka A, Meerbeek BV. Self-assembled nano-layering at the adhesive interface. J Dent Res, 2012; 91(4):376-381.

67. Toledano M, Osorio R, Osorio E, Aguilera FS, Yamauti M,Pashley DH, Tay F. Durability of resin-dentin bonds: effects ofdirect/indirect exposure and storage media. Dent Mater, 2007; 23(7):885-892.

68. Feitosa VP, Leme AA, Sauro S, Correr-Sobrinho L, Watson TF, Sinhoreti MA, Correr AB. Hydrolytic degradation of the resin-dentine interface induced by the simulated pulpal pressure, direct and indirect water ageing. J Dent, 2012; 40(12):1134-1143.

69. Koshiro K, Sidhu SK, Inoue S, Ikeda T, Sano H. New concept of resin-dentin interfacial adhesion: the nanointeraction zone. J Biomed Mater Res B Appl Biomater, 2006; 77:401-408.

70. Muñoz MA, Luque-Martinez I, Malaquias P, Hass V, Reis A, Campanha NH, Loguercio AD. In Vitro Longevity of Bonding Properties of Universal Adhesives to Dentin. Oper Dent, 2015; 40(3):282-292.

71. Perdigao J, Sezinando A, Monteiro PC. Laboratory bonding ability of a multi-purpose dentin adhesive. American $\mathrm{J}$ Dent, 2012; 25(3):153-158.

72. Sofan E, Sofan A, Palaia G, Tenore G, Romeo U, Migliau G. Classification review of dental adhesive systems: from the IV generation to the universal type. Annali di Stomatologia, 2017; 8(1):1-17.

73. Hashimoto M, Ito S, Tay FR, Svizero NR, Sano H, Kaga M, Pashley DH. Fluid movement across the resin-dentin interface during and after bonding. J Dent Res, 2004; 83(11):843-848.

74. Osorio R, Yamauti M, Ruiz-Requena ME, Toledano M. MMPs activity and bond strengthin deciduous dentineresin bonded interfaces. J Dent, 2013; 41(6):549-555.

75. Perdigão J, Reis A, Loguercio AD. Dentin adhesion and MMPs: a comprehensive review. J Esthetic Rest Dent, 2013; 25(4):219-241.

76. Sabatini C. Effect of phosphoric acid etching on the shear bond strength of two self-etch adhesives. J Appl Oral Sci, 2013; 21(1):56-62.

77. Ribeiro AIAM, Dantas DCRE, Guênes GMT, Araújo RKP, Cyrilo CC, Braz R. Action of deproteinizing and anti- oxidant agents on the microtensile bond strength of conventional adhesives. RGO - Rev Gaúcha Odontol, 2011; 59(2):221-227.

78. Liu Y, Tjäderhane L, Breschi L, Mazzoni A, Li N, Mao J, Pashley DH, Tay FR. Limitations in bonding to dentin and experimental strategies to prevent bond degradation. $\mathrm{J}$ Dent Res, 2011; 90(8):953-968.

79. Brackett MG, Li N, Brackett WW, Sword RJ, Qi YP, Niu LN, Pucci CR, Dib A, Pashley DH, Tay FR. The critical barrier to progress in dentine bonding with the etch-andrinse technique. J Dent, 2011; 39(3):238-248.

80. Hashimoto M, Ohno H, Kaga M, Endo K, Sano H, Oguchi H. In vivo degradation of resin-dentin bonds in humans over 1 to 3 years. J Dent Res, 2000; 79:1385-1391.

81. Wang Y, Spencer P. Quantifying adhesive penetration in adhesive/dentin interface using confocal Raman microspectroscopy. J Biomed Mater Res, 2002; 59:46-55.

82. Spencer P, Wang Y, Walker MP, Wieliczka DM, Swafford JR. Interfacial chemistry of the dentin/adhesive bond . J Dent Res, 2000; 79:1458-1463.

83. Mena-Serrano A, Kose C, De Paula EA, Tay LY, Reis A, Loguercio AD, Perdigão J. A new universal simplified adhesive: 6-month clinical evaluation. J Esthet Restor Dent, 2013; 25(1):55-69.

84. Perdigão J, Kose C, Mena-Serrano AP, De Paula EA, Tay LY, Reis A, Loguercio AD. A New Universal Simplified Adhesive: 18-Month Clinical Evaluation. Oper Dent, 2014; 39(2):113-127.

85. Ito S, Hashimoto M, Wadgaonkar B, Svizero N, Yiu CK, Rueggeberg FA, Foulger S, Saito T, Nishitani Y, Yoshiyama M, Tay FR, Pashley DH. Effects of resin hydrophilicity on water sorption and changes in modulus of elasticity. Biomaterials, 2005; 26(33):6449-6459.

86. Nishitani Y, Yoshiyama M, Donnelly AM, Agee KA, Sword J, Tay FR, Pashley DH. Effects of resin hydrophilicity on dentin bond strength. J Dent Res, 2006; 85(11):1016-1021.

87. Hosaka K, Nakajima M, Takahashi M, Itoh S, Ikeda M, Tagami J, Pashley DH. Relationship between mechanical properties of one-step self-etch adhesives and water sorption. Dent Mater, 2010; 26(4):360-367.

88. Chai Y, Lin H, Zheng G, Zhang X, Niu G, Du Q. Evaluation of the micro-shear bond strength of four adhesive systems to dentin with and without adhesive area limitation. Biomed Mater Eng, 2015; 26(1):S63-S72.

89. Armstrong SR, Keller JC, Boyer DB. Mode of failure in the dentin-adhesive resin-resin composite bonded joint as determined by strength-based ( $\mu$ TBS) and fracture-based (CNSB) mechanical testing. Dent Mater, 2001; 17(3): 201-210. 